\title{
Construction Duration Determinants of Building Projects in Sarawak
}

\author{
Ahmed Mohammed Kamaruddeen, Yap Wan Keat, Ibrahim Jibrin Abubakar \\ ${ }^{\mathrm{a} \& \mathrm{~b}}$ Quantity surveying programme, University College of Technology Sarawak \\ ${ }^{c}$ Department of Urban and Regional Planning, Bayero University Kano \\ Corresponding author: kamaruddeen@ucts.edu.my
}

\begin{abstract}
This research utilized the quantitative method and stratified simple random sampling technique to collect data with a view to investigating the determinants of construction duration of building projects in Sarawak. Out of the 180 copies of questionnaire distributed to grade 4, 5, 6 and 7 contractors operating within Bintulu and Sibu in Sarawak, only 36 copies were duly completed, making the valid response rate to be 20 percent. Descriptive analysis and Relative Importance Index (RII) were utilized in analysing the data. The descriptive analysis revealed that availability of construction site, type of building constructed and market condition are the important determinants of construction duration. The result of relative importance index revealed that the availability of construction site is the highest determinant. This study has complemented the existing knowledge on the determinants of construction duration.
\end{abstract}

Keywords: construction duration, determinants of construction duration, building projects, Sarawak

\section{Introduction}

According to Rahman et al. (2013), the construction industry in Malaysia has been playing a major role in the country's economic growth. Memon et al. (2013) stated that the industry has been providing essential socio-economic infrastructure such as offices, roads and schools for the improvement of the quality of people's lives. For this industry to continue to transform the needs and aspiration of people into reality, as Malaysia marches progressively towards industrialization, there is need for it to be greatly enhanced.

Besides, building construction is also known as one of the important elements for the Malaysian construction industry, and about $67.6 \%$ of the overall construction work is provided by it (CIDB, 2008). If construction companies in collaboration with their developers focus on short term goals, it may result in the neglect of the future goals of the building construction activities. This situation therefore calls for the need to focus more on erecting strong buildings that can stand the challenges in the world today. For this reason, it is preferable to be engaged in new strategic decisions and measures regarding the evaluation of building projects so as to sharpen the contractors' competitive edge.

Project's success can be defined as the attainment of the required project's quality under a scheduled duration together with a specified budget (Project Management Institute, 2000). At the early stages of development, one of the elements 
that enhance the success of a project is the determination of the construction duration since this element forms the foundation for budgeting, executing, monitoring, planning and even the litigation aims (Skitmore and $\mathrm{Ng}$, 2003). In order to provide predictions that are accurate, empirical models have been developed (Bromilow, 1969; Khosrowshahi and Kaka, 1996). However, the complex interaction of the numerous attributes of construction projects can influence the construction duration.

According to the availability of projects data and duration of time, estimation of duration at different stages of project construction is essential for the construction phase planning. For the valuation of the performance and success of building projects, three criteria which are cost, time and quality have been used for a long time (Chan et al., 2002). These criteria have been named by Atkinson (1999) as "the iron criteria". Also, the study by Chan and Kumaraswamy (1995) showed that the individual intuition, skill and experience of the planning engineer are needed in order to have the ability to estimate a project's completion time. General contractors who can accurately predict the construction duration and then finish the job within the given time are highly considered in the construction industry. The reason is that the contractor's ability to make good decisions is highly instrumental to preventing negative impact such as delays in the completion of the building project.

\section{Malaysian Construction Industry}

The construction industry is an investment for economic purposes. This suggests that there is relationship between construction industry and economic development. The contribution of the construction industry to national economic development is highlighted in the literature (Sambasivan and Soon, 2007; Myers, 2013; Khan et al., 2014). Malaysia is aiming at achieving a high-income status by 2020 which will involve intensive transformation for the economic structure. A five-year strategic thrusts plan is in place for the economic transformation. While working towards the 2020 target, the challenge then will be on how to sustain or increase the 6.0\% GDP (Gross Domestic Product) per annum during the Tenth Plan Period. Therefore, one of the economic sectors, which is the construction industry, must actively play its roles through policy formulation and implementations. The comparison of the contribution of the Malaysian construction industry with construction industries in other countries showed that Malaysian construction industry has been consistently stable. Between 2003 and 2013, the comparison of the Malaysian construction industry with other Asian countries such as South Korea, Hong Kong, Singapore and Taiwan revealed that, though Malaysian construction industry's contribution is not the highest but it has remained moderate (Department of Statistics Malaysia 2014).

\section{Determinants of Building Projects Duration}

In this paper, project duration refers to the actual completion date of a building project. This period includes any overrun time on the project that is not caused by the complete suspension of site operations. According to Hamzah et al. (2011), time overrun is a delay in the completion of a project beyond the agreed contractual time. According to Chan and Kumaraswamy (1997), completing projects within the given time is an indicator of a more efficient construction industry. However, referring to Chan and Kumaraswamy (2002), construction delay happens in many countries especially for projects involving public infrastructure. This negative impression is not good for the construction industry because project success involves the evaluation of time performance besides cost, quality and value-for-money which are the basic criteria 
(Endut, 2008). Research has shown that the factors responsible for the time overrun can vary completely from one project to another (Endut et al., 2006).

Project overruns has negative impact on the reputation of the construction industry, and this is why the Malaysian government has intensified efforts in reducing the possibility of its occurrence (Enshassi et al., 2009). While there are various factors that can cause time overrun, the best strategy is to minimize or prevent its occurrence (Shebob et al., 2011). A major implication of time overrun is that cost overrun and time are always correlated in positive way. For example, project time overrun might lead to the increase of the project's cost, thereby resulting in serious troubles on construction projects globally (Enshassi et al., 2009). Besides, time and cost overrun can occur from lack of necessary project information (Endut, 2008) or inexperienced construction team (Sweis et al., 2008). Other factors might include harsh environmental conditions, public or private projects, financial value and physical size of a project, the employed tendering method and project procurement route (Endut, 2008).

\section{Project Cost}

Construction project have been classified by Construction Industry Development Board of Malaysia (CIDB) into small (contract values less than RM3 million), medium (contract values more than RM3 million but less or equal to RM50 million) and major (contract values more than RM50 million) (CIDB, 2005). The major projects might exhibit complexity besides urgency of schedule and complexity in terms of the resources involved (Morris and Hough, 1987). According to Flyvbjert et al., (2004), larger projects can be prone to more risk due to delays when compared to the smaller ones. According to Chan and Kumaraswamy (1995), the cost of a project is an essential factor that influences project duration. From a different point of view, Love, Tse and Edwards (2005) argue that cost is a poor indicator of project duration because it is impossible to know the actual completion cost of each project before the work is completed. For example, if there are two projects having similar design and quality of materials, their cost will differ but the duration can still be the same. Despite the diverse opinions on the determinants of construction project duration, there is a correlation between project duration and the cost of the project. For example, when the total duration of the project increases, it also causes the increase in general overhead cost.

\section{Project Related Factors}

Project related factors in this paper refer to the types of building constructed such as office buildings, health care buildings, residential buildings and industrial buildings. Also the technical parameters such as areas and structure of the project site are related factors. It has been pointed out by Nkado (1995); Bhokha and Ogunlana (1999); Chan and Kumaraswsamy $(1999,2002)$ that factors that can affect the project duration are the size, types of building and height of the building. Therefore, when gross floor area increases, the building size also increases which results in longer construction duration. This is because the size of building will affect the quantity of materials to be used, system of construction, procurement system and the technology to be used in constructing the building. As a result, larger building size would require a more experienced project and management teams. Nkado (1995); Bhokha and Ogunlana (1999); Chan and Kumaraswsamy $(1999,2002)$ in the same line of thought stated that the duration of a project is affected by the complexity of the project. If the complexity of the building is low, then the management and construction will be easier. For example, 
a market building may require a shorter time to construct when compared to a hospital building which requires specialization.

\section{Construction Site}

Chan and Kumaraswamy (1995); Karsli (1998); Bhokha and Ogunlana (1999) stated that the construction duration might be significantly affected by the location of a building where there is no easy accessibility to the site. Besides, the accessibility of the site, site conditions such as topography, size of site and ground condition would also affect the duration of the construction. For example, depending on site conditions, different machineries would be required for either back fills or excavations. These additional task might increase the duration of a construction project. Karsli (1998) also states that the location of the site would also affect the given choices as it required a detailed analysis in order to execute the work.

\section{Research Methodology}

This research utilized the quantitative method to obtain data. Stratified simple random sampling was adopted to select the targeted respondents. Respondents for this research consist of contractors categorized as Grade 4, 5, $6 \& 7$ who are registered with the Construction Industry Board (CIDB) in Sarawak State. However, two cities in Sarawak State namely, Sibu and Bintulu were chosen for this research. A total of 37 grade 4 contractors and 50 grade 5 contractors were given copies of questionnaire through their email addresses. Their email addresses were obtained from the Construction Industry Development Board (CIDB) website. A total of 8 copies of the questionnaire from the grade 4 and 5 respectively were returned representing $22.22 \%$. Likewise, 24 grade 6 contractors and 69 grade 7 contractors were also given copies of questionnaire and 10 copies of the questionnaire were returned from each of the grade 6 and 7 representing $27.78 \%$ respectively. Hence, a total of 180 copies of questionnaire were distributed and 36 copies were usable yielding $20 \%$ response rate. The 5-point likert scale was used in the questionnaire to obtain the perception of the respondents on the determinants of construction duration. The questionnaire consist of two parts. The first part consist of questions on the respondent's profile and the second part contains the list of determinants of construction duration that were obtained from the literature. The obtained data was analyzed using both Relative Importance Index (RII) and Microsoft Excel to obtain the descriptive statistics. The purpose of the RII was to identify the highest ranked determinants of construction duration. Table 1 presents the respondents' demographic profile from the two cities: Bintulu and Sibu in Sarawak. 


\section{Results}

Table 1: Demographic Profile of Respondents

\begin{tabular}{llcc}
\hline Description & Respondents & $\begin{array}{c}\text { Frequency } \\
\text { (No. of } \\
\text { Resp.) }\end{array}$ & $\begin{array}{c}\text { Percentage } \\
\text { (\%) }\end{array}$ \\
\hline Position & Director & 5 & 13.89 \\
& Project Manager & 5 & 13.89 \\
& Contractor & 15 & 41.67 \\
& Quantity Surveyor & 4 & 11.11 \\
& Civil Engineer & 7 & 19.44 \\
& Total: & 36 & 100 \\
& & & 16.67 \\
\hline Experience of the Field & Less than 5 years & 6 & 16.67 \\
& 5 to 10 years & 6 & 25.00 \\
& 10 to 15 years & 9 & 19.44 \\
& 15 to 20 years & 7 & 22.22 \\
20 years and above & 8 & 100 \\
\hline Total: & 36 & \\
\hline
\end{tabular}

Contractors constituted about 42 percent of the total respondents. This was followed by civil engineers that accounted for 19 percent of the group. The next group consisted of directors and project managers, each accounted for about 14 percent. The least number is the quantity surveyors who occupied only 11 percent of the group.

Table 2: Determinants of Construction Duration

\begin{tabular}{lccccc}
\hline Determinants & $\begin{array}{c}\text { Mean } \\
\text { Average }\end{array}$ & $\begin{array}{c}\text { Standard } \\
\text { Deviatio } \\
\mathbf{n}\end{array}$ & RII & Rank & $\begin{array}{c}\text { Remark } \\
\text { s* }\end{array}$ \\
\hline Nature of construction site & 4.49 & 0.55 & 0.90 & 1 & Agree \\
Type of building to be constructed & 4.34 & 0.56 & 0.87 & 2 & Agree \\
Level/number of storey & 4.32 & 0.59 & 0.86 & 3 & Agree \\
Size of construction site & 4.31 & 0.56 & 0.86 & 4 & Agree \\
Costs of building to be constructed & 4.04 & 0.60 & 0.81 & 5 & Agree \\
Market condition & 3.67 & 0.59 & 0.73 & 6 & Agree \\
\hline
\end{tabular}

(Note: * Mean Average with $1.00-1.49=$ strongly disagree, $1.50-2.49=$ disagree, $2.50-3.49=$ somewhat agree, $3.50-4.49=$ mostly agree,

Strongly agree $=4.50-5.00$ ) 
Table 2 presents the mean, standard deviation and relative importance index for the determinants of construction duration for building projects. The results showed that the nature of construction area can affect the construction duration for building projects with the mean score of 4.49 while the market conditions are the least factors having the lowest mean of 3.67 in this study. Although the other determinants are between the mean range of 4.00 and 4.34 , the study showed that the type of building to be constructed, level of building to be constructed, size of site and costs of building to be constructed are also determinants that might affect the construction duration for building projects in Sarawak.

\section{Table 3: Nature of Construction Site}

\begin{tabular}{lllll}
\hline Dimension & Mean & Std. Deviation & RII & Rank \\
\hline Limited access to construction site & 4.75 & 0.44 & 0.950 & 1 \\
Partial access to construction site & 4.33 & 0.48 & 0.867 & 2 \\
Easy access to construction site & 4.22 & 0.72 & 0.844 & 3 \\
\hline
\end{tabular}

As shown in Table 3, limited access to construction site has the highest impact on the construction duration with the mean of 4.75. This is followed by partial access to construction site with mean of 4.33 and unrestricted access to construction site with mean of 4.22.The respondents quite agreed that limiting access to the construction site would have negative impact such as cost overrun due to limited access to the site. When the site has limited in access, the contractor in-charge cannot do his job freely until he takes over the site. Productivity is defined as overall site productivity and labour productivity (Chan and Kumaraswamy, 1995). Literature has shown that site productivity is one of the micro factors apart from the macro factors (Chan and Kumaraswamy, 1995). The factors which can affect the site productivity are work space availability and lower productivity rates. According to Al-Moumani (2000), the cause of delays in construction project is related to site conditions. Therefore, lowered site productivity can lead to project delays.

Table 4: Types of building to be Constructed

\begin{tabular}{lllll}
\hline Dimension & Mean & $\begin{array}{l}\text { Std. } \\
\text { Deviation }\end{array}$ & RII & Rank \\
\hline Industrial building & 4.58 & 0.50 & 0.917 & 1 \\
Health care building & 4.53 & 0.51 & 0.906 & 2 \\
Technical purpose building & 4.53 & 0.51 & 0.906 & 2 \\
Building for scientific teaching and & 4.36 & 0.49 & 0.872 & 4 \\
research & & & & \\
Sport complexes & 4.36 & 0.54 & 0.872 & 4 \\
School and nursery schools & 4.28 & 0.66 & 0.856 & 6 \\
Office building & 4.22 & 0.54 & 0.844 & 7 \\
Residential building & 3.89 & 0.71 & 0.778 & 8 \\
\hline
\end{tabular}


As shown in Table 4, the complexity of project can affect construction duration of a project. Industrial building had the mean score of 4.58 . This was followed up by health care building and technical purpose building with both had the mean score of 4.53. Most respondents agree that health care building and technical purpose building may require the specialization of the related field due to specialized machineries and equipment that are used in the building. Nkado (1995), Chan and Kumaraswamy (2002) agreed that the duration of project can also be affected by complexity of project. For example, market building would take a shorter time to complete when compared to a health care building. Besides, if the complexity level of a project is low, then the construction management for the project can easily handle it when compared to big and complex project.

Table 5: Level of Building to be constructed

\begin{tabular}{lllll}
\hline Dimension & Mean & $\begin{array}{l}\text { Std. } \\
\text { Deviation }\end{array}$ & RII & Rank \\
\hline Under ground & 4.44 & 0.50 & 0.889 & 1 \\
Above ground & 4.19 & 0.67 & 0.839 & 2 \\
\hline
\end{tabular}

As shown in Table 5, the construction of underground would influence the construction duration than it would for the construction of superstructure. This is shown by the mean underground score of 4.44 while the above ground had the mean score of 4.19. Tabishl and Jha (2011) concluded that comprehensive site investigation helps in proper planning which in turn helps the contractor to understand the scope and develop mutual understanding. As a result, it will help to decrease the scope changes during construction. Therefore, precise planning of construction would help to ensure that the project can be delivered on time and within budget (Omran et al., 2012)

Table 6: Gross Floor Area/Area of Site

\begin{tabular}{lllll}
\hline Dimension & Mean & $\begin{array}{l}\text { Std. } \\
\text { Deviation }\end{array}$ & RII & Rank \\
\hline Foundation area & 4.64 & 0.49 & 0.928 & 1 \\
Ceiling area & 4.58 & 0.50 & 0.917 & 2 \\
Roof area & 4.50 & 0.65 & 0.900 & 3 \\
External wall area & 4.44 & 0.56 & 0.889 & 4 \\
Circulation area & 4.42 & 0.55 & 0.883 & 5 \\
Usable area & 4.42 & 0.55 & 0.883 & 5 \\
Gross external floor area & 4.42 & 0.50 & 0.883 & 5 \\
Auxiliary area & 4.39 & 0.49 & 0.878 & 8 \\
Technical area & 4.31 & 0.62 & 0.861 & 9 \\
Territory area & 4.25 & 0.73 & 0.850 & 10 \\
Gross internal floor area & 4.22 & 0.50 & 0.844 & 11 \\
Internal wall area & 3.81 & 0.62 & 0.761 & 12 \\
Footprint area & 3.58 & 0.50 & 0.717 & 13 \\
\hline
\end{tabular}

As shown in Table 6, different elements would have different impacts on the construction duration. The result showed that the foundation area would be affected the most (mean of 4.64). Next was the ceiling area which had the mean of 4.58. The least affected area was the footprint area which had the mean of 3.58. According to Chan and 
Kumaraswamy (2002), the building size and height of building are to be listed as factors that can affect the project duration. For example, when the gross floor area of a building increases, the construction duration will be longer. And it is true for the opposite where lower gross floor area of a building results in shorter construction duration.

\section{Table 7: Cost of Construction Project}

\begin{tabular}{lcccc}
\hline Dimension & Mean & $\begin{array}{c}\text { Std. } \\
\text { Deviation }\end{array}$ & RII & Rank \\
\hline Total amount of superstructure & 4.50 & 0.51 & 0.900 & 1 \\
costs & & & & \\
Site & 4.42 & 0.50 & 0.883 & 2 \\
Total amount of finishing costs & 4.42 & 0.50 & 0.883 & 2 \\
External works & 4.31 & 0.52 & 0.861 & 4 \\
Technical installation and services & 4.06 & 0.67 & 0.811 & 5 \\
Clearance and development & 3.89 & 0.75 & 0.778 & 6 \\
Construction works & 3.83 & 0.77 & 0.767 & 7 \\
Incidental building costs & 3.72 & 0.45 & 0.744 & 8 \\
Furnishing furniture and artistic & 3.25 & 0.73 & 0.650 & 9 \\
appointments & & & & \\
\hline
\end{tabular}

As shown in Table 7, the total amount of superstructure costs had the highest influence on the construction duration (mean is 4.50). Next was site and total amount of finishing costs both having the same mean scores (4.42). The least dimension of cost determinants was furnishing, furniture and artistic appointments which had the mean of 3.25. Costs related determinants also include the capability of the client to pay up on time. Therefore, when the client does not have the capability to pay such an amount, it would affect construction duration of the building project. A study conducted by Alaghbari et al. (2007) revealed that one of the factors that can affect construction time is financial difficulties and economic problems.

Table 8: Market Condition

\begin{tabular}{lllll}
\hline Dimension & Mean & Std. Deviation & RII & Rank \\
\hline $\begin{array}{l}\text { Unfavourable market } \\
\text { conditions for building industry }\end{array}$ & 4.36 & 0.72 & 0.872 & 1 \\
$\begin{array}{l}\text { Favourable market conditions } \\
\text { for building industry }\end{array}$ & 3.69 & 0.58 & 0.739 & 2 \\
$\begin{array}{l}\text { Neutral market conditions for } \\
\text { building industry }\end{array}$ & 3.44 & 0.50 & 0.689 & 3 \\
\hline
\end{tabular}

As shown in Table 8, economic downturn can have a negative impact on the market conditions resulting in a slowdown in the construction activities. This dimension had a mean score of 4.36 which was the highest among the three of them. However, when the market is on the booming site, it will also affect the construction duration, 
although it does not affect as much as when it is unfavourable. According to Frimpong and Oluwoye (2003), one of the factors that can negatively affect the construction duration is poor economic conditions. The construction activity is very sensitive to changes especially in the local and national economy. Due to the cyclical nature of construction activity, it will rise when there is growth in economy and suffers when the economy is downturned.

\section{Table 9: Ranked determinants of Construction Duration}

\begin{tabular}{lll}
\hline Determinants & RII & Rank \\
\hline $\begin{array}{l}\text { Availabilty of construction } \\
\text { area }\end{array}$ & 0.90 & 1 \\
$\begin{array}{l}\text { Type of building to be } \\
\text { constructed }\end{array}$ & 0.87 & 2 \\
$\begin{array}{l}\text { Level/number of storey } \\
\text { Size of construction site }\end{array}$ & 0.86 & 3 \\
$\begin{array}{l}\text { Costs to affect construction } \\
\text { duration }\end{array}$ & 0.86 & 4 \\
Market condition & 0.81 & 5 \\
\hline
\end{tabular}

Table 9 presents the summary of the determinants of construction duration base on the results of Relative Importance Index (RII). Nature of construction site was ranked first (0.90), and type of building constructed was ranked second in order of relative importance index (0.87). Level of building under construction (0.86) and location of site (0.86) were both ranked third. Size and cost was ranked fourth (0.81). Market condition was ranked fifth (0.73).

\section{Discussion}

According to Dursun and Stoy (2012), the most reported determinant of construction duration in the literature is the cost of the project. This is largely due to the linkage of project cost to other determinants such as nature of construction site, number of levels, types of building projects and market condition. For example, as the number of building level increases, the duration and cost of the project increases. The highest ranked determinant in this research is the nature of construction site (0.9) with mean score of 4.49. This finding is consistent with Chan and Kumaraswamy (1995); Karsli (1998); Bhokha and Ogunlana (1999). Nature of construction site is ranked highest probably due to the nature of ground in Sibu and Bitulu town. The nature of ground require the use of pile foundation for most building projects. The second ranked determinant of building project is the type of building project (0.87), having a mean score of 4.34. This finding is consistent with Chan and Kumaraswamy (1995); Karsli (1998); Bhokha and Ogunlana (1999). The third ranked determinant of building project is number of building level (4.32), having a mean score of 0.86 . This finding is consistent with Love et al. (2005). Market condition is ranked the least determinant of construction duration (0.73), having a mean score of 3.67. This is probable because most respondents perceived market condition as having no direct or weak influence on the construction duration of building projects. One dimension of market condition examined in this 
research is unfavourable market condition. Unfavourable market condition could result in the scarcity or over supply of building materials in the market, but might not necessarily have a significant impact on the construction duration of building projects in Sarawak.

\section{Conclusion}

This paper has identified six determinants of construction duration in Sarawak, Malaysia. The highest determinant is the nature of construction site and least determinant is the market condition. This paper has complemented the existing body of knowledge regarding the factors that could determine the construction duration of building projects. A major implication of this research is that contractors and other construction professionals such as project managers should give considerable attention to the nature of site while estimating the completion time of a building project. The small response rate of 20 percent is considered a major limitation to this study. Future research can explore other determinants of construction duration and their influence on other types of construction projects such as road construction.

\section{References}

Alaghbari W, Kadir MRA, Salim A, Ernawati. (2007). The significant factors causing delay of building construction projects in Malaysia, Engineering, Construction and Architectural Management, 14 (2), 192-206.

Al-Moumani, H.A. (2000). Construction delay: a quantitative analysis, International Journal of Project Management, 18, 51-9.

Al-Tmeemy, S. M. H. M., Abdul-Rahman, H., \& Harun, Z. (2011). Future criteria for success of building projects in Malaysia. International Journal of Project Management, 29 (3), 337-348.

Atkinson, R. (1999). Project management: cost, time and quality, two best guesses and a phenomenon, its time to accept other success criteria, International Journal of Project Management, 17(6), 337-342.

Bhokha, S., and Ogunlana, S. (1999). Application of artificial neural network to forecast construction duration of buildings at the predesign stage, Engineering, Construction and Architectural Management, 6 (2), 133-144.

Bromilow, F.J. (1969). Contract time performance expectations and the reality. Building

Forum, 1(3), 70-80.Chan, A., Scott, D. and Lam, E. (2002). Framework of Success Criteria for Design/Build Projects. Journal of Management in Engineering, 18 (3), 120-128.

Chan, D., and Kumaraswamy, M. (1995). A study of the factors affecting construction durations in Hong Kong, Construction Management and Economics, 13 (4), 319333.

CIDB. (2008). Construction industry development board Malaysia. Construction Statistics Malaysia, Kula Lumpur.

Department of Statistics Malaysia. (2014). Annual Gross Domestic Product 2005-2013, ISSN 1955-0751.Department of Statistics Malaysia. (2014). Quarterly construction statistics, First Quarter 2014. 
Dursun, O. and Stoy, C. (2011). Time-cost relationship of building projects: statistical adequacy of categorisation with respect to project location, Construction Management and Economics, 29 (1), 97-106.

Dursun, O. and Stoy, C. (2012). Determinants of construction duration for building projects in Germany, Engineering, Construction and Architectural Management, 19 (4), $444-468$.

Endut, I. R. (2008). Framework for avoiding cost overruns in Malaysian construction projects (Ph.D.), Glasgow Caledonian University, Glasgow.

Endut, I.R., Akintoye, A. and Kelly, J. (2006). Relationship between duration and cost of Malaysian construction projects, paper presented at the International Conference in the Built Environment in the 21st Century (ICiBE 2006), Kuala Lumpur, 13-15 June 2006.

Enshassi, A., Al-Najjar, J. and Kumaraswamy, M. (2009). Delays and cost overruns in the construction projects in the Gaza Strip, Journal of Financial Management of Property and Construction, 14 (2), 126-151.

Flyvbjerg, B., Holm, M., and Buhl, S. (2004). What causes cost overrun in transport infrastructure projects? Transport Reviews 24 (1), 3-18.

Frimpong, Y. and Oluwoye, J. (2003). Significant factors causing delay and cost overruns in construction of groundwater projects in Ghana. Journal of Construction Research, 4 (02), 175-187.

Hamzah, N., Khoiry, M.A., Arshad, I., Tawil, N.M. and Ani, A.I. (2011). Causes of delay - theoretical framework, The 2nd International Building Control Conference 2011, Procedia Engineering, 20, 490-495.

Hoffman, G.J., Thal, A.E. Jr, Webb, T.S. and Weir, J.D. (2007), Estimating performance time for construction projects, Journal of Management in Engineering, 23 (4), 193-199.

Khan, R.A., Liew, M.S., and GhazaliZ. B. (2014). Malaysian Construction Sector and Malaysia Vision 2020: Developed Nation Status, Procedia - Social and

Behavioural Sciences 109, 507 - 513.

Khosrowshahi, F. and Kaka, A.P. (1996). Estimation of project total cost and duration for housing projects in the UK, Building and Environment, 31 (4), 375-83.

Love, P.E.D., Tse, R.Y.C. and Edwards, D.J. (2005). Time-cost relationships in Australian building construction projects, Journal of Construction Engineering \& Management, 131 (2), 187-94.

Morris, P.W.G. and Hough, G.H. (1987). The Anatomy of Major Projects, Wiley, New York, NY.Myers, D. (2013). Construction Economics: A new approach (3rd Ed.). New York: Routledge.

Ogunsemi, D.R. and Jagboro, G.O. (2006). Time-cost model for building projects in Nigeria, Construction Management \& Economics, 24 (3), 253-8.

Omran, A., Abdalrahman, S., and Pakir, A.H.K. (2012). Project Performance in Sudan Construction Industry: A Case Study, Academic Research Journals (India), 1 (1), $55-78$.

Project Management Institute. (2000). A Guide to the Project Management Body of Knowledge (2000 Ed.).

Rahman, I. A., Memon, A. H., and Karim, A. T. A. (2013). Significant factors causing cost overruns in large construction projects in Malaysia, Journal of Applied Sciences, 13 (2), 286-293. https://doi.org/10.3923/jas.2013.286.293.Sambasivan M, and Soon Y. W. (2007). Causes and Effects of delays in Malaysian construction industry, International Journal of Project Management, 25 (5), 517-526. 
Shebob, A., Dawood, N. and Xu, Q. (2011). Analysing construction delay factors: a case study of building construction project in Libya, in Egbu, C. and Lou, E.C.W. (Eds), Procs 27th Annual ARCOM Conference, Association of Researchers in Construction Management, Bristol, 1005-1012.

Skitmore, R.M. and Ng, S.T. (2003). Forecast models for actual construction time and cost, Building and Environment, 38 (8), 1075-83.

Sweis, G., Sweis, R., Hammad, A.A. and Shboul, A. (2008). Delays in construction projects - thecase of Jordan, International Journal of Project Management, 26 (6), 665-674.

Tabishl S. Z. S., and Jha, K. N. (2011). Important Factors for Success of Public Construction Projects. 2nd International Conference on Construction and Project Management. Singapore. 